\title{
Evaluation of EU Cohesion Policies within the scope of Lisbon and Europe 2020 Strategies
}

\author{
Asc.Prof.Dr. İclal Kaya Altay \\ MSGSÜ Department of Urban and Regional Planning,
}

Shqiprim Ahmeti

MSGSÜ Department of Urban and Regional Planning, M.S. Thesis Student

\begin{abstract}
In order to increase the level of integration and development at the scale of the Union and to raise the conditions of competition on a global scale, EU has announced two basic development strategies within the process: Lisbon Strategy (2000) and the Europe 2020 Strategy (2010). Though the EU 2000-2006 Cohesion Policies corresponding to the 2000-2006 fiscal period and 2007-2013 Cohesion Policy Program that was reformed in comparison to the previous program were prepared within the scope of the Lisbon Strategy, 2014-2020 financial program and Cohesion Policies have been produced within the context of EUROPE 2020 Strategy. During the said process, the objectives and priorities as well as the budgets of the EU structural funds have changed. In March 2000, the European Council meeting in Lisbon set the strategic goal of transforming the EU into 'the most competitive and dynamic knowledge-based economy in the world' within a decade. Among the jointly agreed goals to be attained by 2010 were raising investment in research and development to three per cent of gross domestic product (GDP) and increasing the rate of employment within the EU from 61 to 70 per cent of the working-age population (Teasdale, 2012). Based on the interim evaluations of Lisbon Strategy, EU Commission stated that the required specific objectives could not be achieved because the financial crisis and planned reforms could not be implemented. At the same time, the major expansion in 2004 made the existing interregional disparities more evident. Published on 2010 by EC, Europe 2020 Strategy (which is considered to be a reviewed and updated Lisbon Strategy) brought in a new expansion in terms of achieving the initial objectives. The strategy in question focuses not only on the economic - social cohesion but also on spatial cohesion. However, the statistics within the process reveal that the economic, social and territorial cohesion could not be achieved at the scale of EU yet, even it has been asserted in a report, which was prepared by the Secretariat of the Conference of Peripheral Maritime Regions (CPMR) in 2015 that besides the disparities between the Member States, disparities between regions within countries increased, as well. Within the scope of this study, it will be discussed how much the cohesion target, given in the founding treaty of EU is reflected on the development strategies; the role and accomplishments of these strategies and funds in achieving that target. While the role and accomplishments of the Europe 2020 Strategy, which is still in effect today, are questioned in terms of ensuring particularly the territorial cohesion, also the importance and the priority granted to urban spaces in order to achieve the objectives of strategies - as well as objectives of the founding agreement - will be discussed. The Method of the Study can be summarized as the literature survey based on the Lisbon and Europe 2020 Strategies of European Commission, the EU Financial Period Programs and observations and critics prepared by a variety of institutions as well as the evaluation of the findings based on statistical datas.
\end{abstract}

Keywords: Lisbon Strategy and Europe 2020, EU Structural Funds, Regional/Cohesion Policy and Territorial Cohesion

\section{Introduction}

Boosting the scale of economic and social cohesion, achieving sustainable economic development, achieving a balanced and environment-friendly, sustainable economic development at the scale of the Union has been considered as the community's mission in Article 2 of the Treaty on EU (TEU, 1992,Article 2). The community focused on succeeding in this objective specified in the founding Treaty in such a way that all the policies, including competitiveness, common economic market, regional policies would not be in contrary with the application of open economic market. Achieving the purposes 
such as the presumed future increase in the structure of EU-15 and as the participation of new members under the average GDP level of the Union, strengthening the economic and social structure at the scale of EU and the goal to improve the competitiveness at the global level within the process have brought the Lisbon Strategy (2000) into the agenda.

The Lisbon Strategy ${ }^{1}$ mainly focused on goals of strengthening the opportunities of economic competitiveness of EU on a global scale, finding solution to the problem of increasing unemployment and overcoming the problems in the social security system. Upon the adoption of sustainable development strategies, the scope of the Lisbon Strategy was expanded. The program of cohesion policies for 2000-2006 corresponding to the Fiscal Period 2000-2006 of EU and the program of cohesion policies for 2007-2013 has been prepared within the scope of the Lisbon Strategy.

However, the economic crisis that rocked also the EU as all over the world and the major expansion in 2004 made the existing inter-regional disparities more evident and complicated the implementation of the projected reforms within the context of the Lisbon Strategy. According to the official declarations of EU, despite of the financial, economic reforms and the measures taken under the Lisbon Strategy, the lack of coordination between Member states recognized as one important negative factor, among others.

In the interim assessment of Lisbon Strategy, being confessed with the objective of transforming the EU to "the most competitive, dynamic and knowledge-based economy in the world" until 2010, it has been ascertained that the results achieved at the scale of the Union fell behind the expectations. The findings showing that economic growth, employment levels and GDP fell at a rate of $4 \%$ at EU level as of 2009, brought up the Europe 2020 Strategy in 2010. Important changes are projected within the context of the Europe 2020 Strategy without making any climatic changes in the EU's economic and social infrastructure, without abandoning the sustainable policies in terms of the protection of the environment. The Strategy aims to transform EU into an economy, supporting the social and regional cohesion until 2020, based on knowledge and innovation, by using the resources efficiently, environment-friendly and more competitive, but also creating high-employment (EC, 2010, AKSES, S. IKV, 2013). .

2020 Strategy at the Union scale, described three basic priority areas, consisting of Smart Growth, Sustainable Growth and Comprehensive Growth, 5 goals and 7 initiatives; The EU 2014-2020 fiscal budget focused on the strategic priorities and objectives set out in EUROPE 2020.

\section{AB-2007-2013 Economic Budget Period/ Cohesion Policies and Background}

Though the principle of reducing the regional differences between Member States appears in the Treaty of Rome (EEC), there are not any particular regional policies or funds for this purpose. Its first move was to organize a "Conference on Regional Economies" in December 1961, attended by national administrators with responsibilities in the area and experts in the field. The main outcome was to kick-start a process of reflection on the subject, including the setting up of working groups comparing different experiences and methods, the commissioning of territorial studies, and the promotion of exchanges of experience among national governments. At an institutional level, the output of this work was officially recognised in 1964 in the Community's First Medium-Term Economic Policy Program, which provided the basis for the first Commission Communication (or Memorandum) on Regional policy in 1965.( .......) But the regional policies at EU level have been connected to an official procedure by the establishment of the European Regional Development Fund (ERDF) within the process of adopting the participation of England in the Community after the Paris Summit of 1972-74. However, the fund has a very limited budget compared with the common agricultural fund of the community and Social Fund (David, A. 2005).The total agreed budget for the Fund was 1.3 billion European Units of Account over a three year period (19758), representing around 5 percent of the Community budget. The distribution of resources to each Member State was determined on the basis of a system of national quotas, setting out the percentage share allocated to each Member State. The shares were largely worked out on the basis of inter-state bargaining, linked to net budgetary balances, and did not have a direct, explicit link to Community regional development needs.

The regional policy at the level of the Community and re-arrangement of the funds occurred upon the adoption of The Single European ActSEA (1985). After this date,the total budget of the funds, the European Regional Development Fund (ERDF), European Social Fund (ESF) and the European Guidance and Guarantee Fund (EAGGF) within the EEC, gathered

${ }^{1}$ Although the necessity of " developingthe European Social Model" was mentioned as the ideological dimension of Lisbon Strategy, it is mentioned that the economic structure to provide a more productive and employment at a higher rate should be US type.(Inan,A. 2005). 
under the name of Structural Funds, increased two-fold. Moreover, the amount of the Regional Development Fund (ERDF) has increased under the umbrella of the Structural Funds (Wilims, R.).The change, which was called as reform in the regional policies of the Community is explained with the necessity creating an economically and socially cohesive regional policy within the union, the persistence on building an economic and political unity against the economic and social changes at the global level since the differences of regional development within the community after the expansion towards Greece, Portugal and Spain, which are behind the average development of the EEC,after 1980.

The legal basis was addressed through the Single Act of 1985. The first major Treaty revision constitutionalized Cohesion policy by introducing the specific title of Economic and Social Cohesion. The policy objective was defined as promoting the "overall harmonious development" of the Community and "strengthening economic and social cohesion", particularly by "reducing disparities between the various regions and the backwardness of the least- favored regions" (Article 130a)... The key task of the ERDF was also restated, namely, "to redress the main regional imbalances in the Community through participation in the development and structural adjustment of regions whose development is lagging behind and in the conversion of declining industrial regions" (Article 130c)(Gian Paolo Manzella, Carlos Mendez,2009).

The regional policy of the Community has entered a new era with the founding agreement of EU in 1992. Besides the Structural Funds, the Cohesion Fund has been created for the use of countries in Northern Europe as well as the Southern Europe, consisting of Spain, Portugal and Greece (the countries joining the Community upon the expansions of EU after 1990 and 1980) in order to ensure the economic and monetary union at the level of the Community and increasing the social cohesion. The Cohesion Fund was mainly created for leveraging the procedures on the protection of the environment and improvement of transport, energy infrastructure networks (Williams, R....).In the process, EU regional policy, cohesion fund and structural funds integrated by acting together and start to be called as cohesion policies. Though there are considerations about the Treaty of Rome (Article 158) in the literature of the EU regional policies, that the cohesion policies exist since 1958 because the phrase "the reduction of disparities between the levels of development of various regions" is mentioned within the objectives of the community, economic and social cohesion policies of EU after 1980 based on a different concept within the framework of the regional policies, which the welfare society model is based on and which is the social-economic climate, where the founding Treaty of Rome aroused.The economic-social cohesion and regional policies of EU have been formed on a more competitive neo-liberal economy policy axis.

Despite the aim of the EU cohesion/regional policy is to reduce the regional disparities and increase the social cohesion, regional policy goals are increasingly concerned with optimizing the contribution of regional resources to the creation of economic growth by promoting competitiveness and reducing unemployment. This is true for smaller EU countries where regional differences are comparatively small (Austria, Denmark, Netherlands, Switzerland), as well as larger Member States which have suffered relatively high, nationwide unemployment for much of the past 20 years and which have extensive areas experiencing deep-seated industrial decline and social problems (German Institute for Economic Research and European Policies Research Centre, 2001). Before the expansion of EU in 2000-2004,the countries benefiting the most within the scope of the structural and cohesion funds have been Greece (42.6\%), Portugal (35.2\%), Ireland (26.7\%), the newEast German State (18.9\%), Italy (Mezzogiorno-17.4\%) and Spain (14.7\%) (EC, 2007).

However, within the entire process, the great structural transformation in the regional policies of EU corresponds to the period after the year 2000 when the EU Lisbon Strategy was adopted. Though the EU regional policies and funding structure are always associated with each other, EU was to expand towards the biggest and poorest countries (the former Socialist East European countries) at once after 2004, brought up to revise the regional policies within the context of its target to reach the level of a competitive region at a global scale through economic-social cohesion Union-wide.

The regulations were subsequently approved by the Council between May and July 1999. In line with the Commission's Agenda 2000 communication, four main aims underpinned the reforms. The first was to increase the concentration of support. This led to a reduction in the number of priority Objectives (from six to three) and in the proportion of the Community population eligible for support under the two territorial Objectives 1 and 2 (from 51.3 percent to 40.7 percent of the Community population). Responding to Member State criticisms, there was also a reduction in the number of Community Initiatives from thirteen to four (INTERREG, EQUAL, LEADER AND URBAN) and a corresponding cut in their budgetary allocation (to 5.35 percent of total resources). Increased thematic concentration was also sought in the mainstream programs. Commission guidelines were published to steer Member State priorities for Structural Funds intervention during the programming process, while, in line with the Treaty of Amsterdam, the European Social Fund was increasingly tied to the European employment strategy. (Gian Paolo Manzella and Carlos Mendez 2009) 
The period, when the financial program for 2000-2006 was created, is characterized with the existence of the economic conditions becoming more serious due to the transition to the common currency,the strong financial consolidations all around EU and the increasing unemployment rate that found its equivalent in the Treaty of Amsterdam in 1997. These difficult economic conditions largely explain why, different from previous reforms, the share of funding allocated to Cohesion policy for the 2000-2006 period remained stable. The agreement was reached during the Berlin European Council of March 1999, allocating €213 billion to Cohesion policy, €39.6 billion of which was accounted for by post accession assistance (Gian Paolo Manzella and Carlos Mendez,2009).

In the financial period of 2000_2006 within the context of EU cohesion/region policy, the number of targets was reduced to three, whereas it was six ${ }^{1}$ during the previous period:

Objective 1: adopted as the incentive for the development and structural cohesion of regions lagging in development. Objective 1 and Objective 6 have been unified under this objective in 2000-2006 period. The regions covered by Objective 1, are determined to benefit from the European Regional Development Fund (ERDF), European Social Fund (ESF), European Agricultural Guidance and Guarantee Fund (EAGGF),Fishing Guidance Financial Tool.

Objective 2: considers the support of economic and social change the regions, which are in structural difficulties and socioeconomic transformation. As a part of the former Objective 2 and $5 b$ and $5 a$,the crisis areas depending on the fishing sector are addressed here. These regions are supported by the European Regional Development Fund and European Social Fund.

Objective 3: cover the regions that are not included in Objective 1 and Objective 2. The former Objective 3 and 4 fall under this section. The measures on this issue are supported by the European Social Fund. Transferred by: İncekara, A. \&KılınçSavrul, B., Yıldız and Akdağ, 2006:41).

During the financial program for the period of 2000-2006, the number of the Member States of EU reached 25 but the difference of development between the regions increased almost by two times. Nonetheless, some of the countries receiving aids before exceeded $75 \%$ of the average GDP of EU, they were invited to contribute on developing of the new members. Most of the beneficiaries of cohesion policy are the countries in Central and Eastern Europe now. \% 35.7 (308 billion euros) of the total budget of the EU was allocated to integration policies with the financial perspective of 2007-2013; $62 \%$ of this allocation was related to growth and employment projects.

\subsection{AB-2007-2013 Financial Budget Program, Structural Funds and Cohesion Policies}

The last reform of the Cohesion Policy for the period of 2007-2013 should be analyzed within the context of a mixture of political, economic and financial issues, having deep impacts on the form and content of the policy ${ }^{2}$. The recent expansion towards the Eastern Europe was effective in the re-arrangement of the EU funds. Although the total population of the EU increased around $20 \%$ due to the participation of new member states, GDP increased only around $\% 4-5$. Nearly all regions

\footnotetext{
${ }^{1}$ Objective 1: was determined for the poorest regions with an average GDP of less than $75 \%$ of the EU average. Especially Spain, Portugal, Greece, Italy and East Germany benefited from this target.

Objective 2: was determined for regions with high unemployment rates or regions where job losses are experienced. It is especially defined for Central-Northern Europe regions with old production technologies, industrial area degradation, and some regions of Italy and Spain.

Objective 3 and 4: were defined fight against long-term unemployment, creating new jobs for the young population. Britain, France, Germany, Spain and Italy are the countries that benefit the most of this target.

Objective 5: It is aimed to help agricultural and rural areas.

Objective 6: After the expansion of the Union in 1995, this target was added for the low density regions of Northern Europe.

${ }^{2}$ For a detailed review of thecontext, debate, negotiationsand final agreement on the 2006 reform see: Bachtler J andWishlade F (2004), SearchingforConsensus: TheDebate on Reforming EU CohesionPolicy, in EuropeanPolicyResearchPapers, No 55,

EuropeanPoliciesResearchCentre, University of Strathclyde, Glasgow; Bachtler J andWishlade F (2005),

FromBuildingBlockstoNegotiatingBoxes: The Reform of EU CohesionPolicy, in EuropeanPolicyResearchPapers, No. 57,

EuropeanPoliciesResearchCentre, University of Strathclyde, Glasgow. Bachtler J, Wishlade F andMendez C (2007), New Budget, New Regulations, New Strategies: The 2006 Reform of EU CohesionPolicy, in EuropeanPolicyResearchPapers, No. 63,

EuropeanPoliciesResearchCentre, University of Strathclyde, Glasgow. 47 Facingthechallenge,

theLisbonstrategyforgrowthandemployment, Report fromthe High Level GroupchairedbyWim Kok, November 2004. 48 Sapir A. et al.

(2004), op.cit.
} 
of the new members are within the scope of Objective 1 of the EU and under the average GDP of 75\% (David.A,2005). Therefore, the benefiting of the new members from the structural funds for the period of 2007-2013, has been a subject for debates among the EU -15 countries.

Another important contextual factor was the increasing importance being attached to the EUs growth and jobs agenda. The Lisbon Strategy was formally launched in 2000, but the lacklustre performance of the EU economy and the difficulties in implementing the program soon became evident.( ManzellaG,P,and Mendez.C,2009).). In the third Report on the economic and social cohesion (EuroActivFebruary 19, 2004), a large-scale revision of the cohesion policy within the context of the 2007-2013 budget has been requested. On 15 July 2004, the Commission proposed a new legislation package, aiming to spend cohesion funds for the objectives contained in the Lisbon (innovation, growth, employment) and Götenburgh2001 (sustainable development) strategies.

Following the inter-institutional agreement in April 2006, the overall amount of resources available for Cohesion policy over the 2007-13 period was set at $€ 347$ billion, representing 35.7 percent of the EU budget. The regulatory package was approved in July 2006, embodying the most radical reform of the policy since 1988 .A key aim was to introduce a more strategic approach for targeting EU priorities, centered on the Lisbon strategy and involving a new planning framework. Strategic EU objectives for Cohesion policy were identified in Community Strategic Guidelines (CSG), while the Member States set out national objectives and a strategy in line with the CSG in a National Strategic Reference Framework (NSRF). Together, these two documents provided the basis for the design of the operational programs. A "Lisbon earmarking" instrument was also introduced, whereby Member States agree to focus the available resources on specific categories of expenditure directly related to Lisbon themes. (ManzellaG, P, and Mendez.C,2009).

In June / July 2006, both the Council and EU Parliament came to an agreement on the debated reform (EC,2007). In this regard, the following objectives of the EU cohesion policies have been specified as below:

- Convergence ${ }^{1}$ (former Objective 1): Supporting growth and job creation in the least developed Member States and regions,. The regions having a per capita GDP less than $75 \%$ of the EU average (mostly regions of the new Member States) will be funded.

- Competitiveness and employment (former Objective 2): Designed for the assistance of the rich Member States in the issues of economic and social change, globalization and the transition to the information society. The employment initiatives shall be formed by taking the European Employment Strategy (EES) into consideration.

- Regional cooperation: Designed for promoting cross-border cooperation programs to find common solutions to the issues such as urban, rural and coastal development, development of economic relations and networking of SMEs.Establishment of a new authority to manage the cooperation programs".

In terms of financial resources, the Council of Europe allocated 307.6 billion $€$ for the cohesion policy for the years 20072013 as of December 17, 2005. 81,7\% of these funds were reserved for the objective of convergence, $15.8 \%$ was reserved for objective of competitiveness and $2.44 \%$ was reserved for European Territorial Cooperation (EC,2007).

\footnotetext{
${ }^{1}$ Economic Growth Theories and the Convergence; When one mentions real convergence between countries/regions, it generally means the approximation of the levels of economic welfare across those countries/regions. Economic welfare of a country is generally proxied by GDP percapita. For that reason, the question of real convergence is related to economic growth. (Aktar, nagiahan) There are conflicting views in the literature regarding the relationship between convergence and economic integration. Two main economic growth theories arriving at opposite conclusions can be cited, the neoclassical growth theories and the endogenous growth theories. The differences in points of view are caused by diverging beliefs in the underlying assumptions on econornic growth. The neoclassical Solow theory points out the importance of the capital accumulation and technological progress in the process of economic growth of countries (Robert M. Solow, 1956.). returns to capital, the model states that output per worker can rise if and only if the technological progress takes place. Endogenous growth theories developed in the 1980's, on the otherhand, emerged as an attempt of understanding the forces behind technological progress which the Solow model leaves it out as unexplained. Asserting that income convergence between rich and poor countries/regions may not be the only possible outcome, they emphasize the research and development efforts in the accumulation of new ideas' (Romer, 1990) and the role of human capital (Lucas, 1988) in the production of goods (for more details:...)
} 
The structural funds and community initiatives in the period of 2000-06 were replaced by a new structure that simplifies the system. The differences between the cohesion policy for 2007-2013 and the previous period are as follows:

In the period 2007-2013, Urban II and Equal initiatives have been taken under the convergence and cross-regional competitiveness \&employment objectives.

Three new objectives contain Interreg III, Equal and Urban II, which are the former community initiatives and the missions of Objectives 1, 2 and 3 where the funds were reserved in the previous financial periods.

Interreg IIIhas been integrated into the European Regional Cooperation objectives.

Urban II and Equal programs have been integrated into the Convergence, Regional Competitiveness and Employment objectives.

Leader + program and the European Agricultural Guidance and Guarantee Fund (EAGGF) were replaced by the European Rural Agricultural Development Fund (EAFRD).

Fisheries Guidance Financial Instrument (FIFG) was replaced by the European Fisheries Fund (EFF). EAFRD and EFF have their own legal basis and will not be addressed together with cohesion now (EC,2007).

\begin{tabular}{|c|c|c|c|}
\hline \multicolumn{4}{|c|}{ The cohesion policy architecture } \\
\hline \multicolumn{2}{|c|}{ 2000-06 } & \multicolumn{2}{|c|}{$2007-13$} \\
\hline $\begin{array}{l}\text { Objectives } \\
\text { Community Initiatives } \\
\text { Cohesion Fund }\end{array}$ & Financial instruments & Objectives & $\begin{array}{l}\text { Financial } \\
\text { Instruments }\end{array}$ \\
\hline $\begin{array}{l}\text { Objective } 1 \\
\text { Regions lagging behind in } \\
\text { development terms }\end{array}$ & $\begin{array}{l}\text { ERDF } \\
\text { ESF } \\
\text { EAGGF-Guarantee } \\
\text { EAGGF-Guidance } \\
\text { FIFG }\end{array}$ & Convergence & $\begin{array}{l}\text { ERDF } \\
\text { ESF } \\
\text { Cohesion Fund }\end{array}$ \\
\hline Cohesion Fund & Cohesion Fund & & \\
\hline $\begin{array}{l}\text { Objective } 2 \\
\text { Economic and social conversion } \\
\text { zones }\end{array}$ & $\begin{array}{l}\text { ERDF } \\
\text { ESF }\end{array}$ & $\begin{array}{l}\text { Regional } \\
\text { competitiveness }\end{array}$ & \\
\hline $\begin{array}{l}\text { Objective } 3 \\
\text { Training systems and } \\
\text { employment policies }\end{array}$ & ESF & employment & ESF \\
\hline Interreg III & ERDF & European & \\
\hline URBAN II(*) & ERDF & $\begin{array}{l}\text { territorial } \\
\text { cooperation }\end{array}$ & ERDF \\
\hline EQUAL $(*)$ & ESF & & \\
\hline Leader + & EAGGF-Guidance & & \\
\hline $\begin{array}{l}\text { Rural development and } \\
\text { restructuring of the fishing sector } \\
\text { beyond Objective } 1\end{array}$ & $\begin{array}{l}\text { EAGGF-Guarantee } \\
\text { FIFG }\end{array}$ & & \\
\hline $\begin{array}{l}4 \text { objectives } \\
4 \text { Community initiatives } \\
\text { Cohesion Fund }\end{array}$ & 6 instruments & 3 objectives & 3 instruments \\
\hline
\end{tabular}

Figure 1: The New Cohesion Policy Architecture

Source: $(E C, 2007)$

The greatest innovation in structuring the EU Funds in the 2007-2013 fiscal period ${ }^{1}$ is the cohesion fund functioningindependentlyno longer. The Cohesion Fund, together with the ERDF and ESF function in line with the objectives

${ }^{11}$ EuropeanRegional Development Fund: Theregulation on the EuropeanRegional Development Fund (ERDF) definesits role andfields of interventionssuch as thepromotion of publicandprivateinvestmentshelpingtoreduceregionaldisparitiesacrosstheUnion. The ERDF 
of the cohesion funds, cohesion policy. Therefore, the same programmingis subject to the rules of management and control (for details, see the General Administration).

Through this new cohesion policy, the Commission aimed to achieve the following objectives:

- Strategic approach:Auditingthe entire programming processes at national and local levels, which will be executed by EU per a single political document (Community Strategic Guides) in the issues of growth, socio-economic and political regional integration

- Simplification: reducing the number of objectives and regulations; single funded programs; streamlined eligibility rules for expenses; more flexible financial management; more emphasis on monitoring, evaluation and control.

- Decentralization/ stronger involvement of regional and local actors in the preparation of programs (EC, 2007-2013).

\subsection{Discussions on Cohesion Policy Achievements Over the Period of 2007-2013}

The European Commission assesses the Cohesion Policies of 2007-2013 periods successful on the basis of independent expert evaluations.

In the report titled "9 Ways Cohesion Policy Works For Europe-Main Results 2007-2013"1",issues such as creation of employment, positive effects on the reduction of regional differences, effects on the increase in GDP etc., are shown as the indicators of success. 2.74 EURO extra GDP until 2023and the cohesion policy investments constitute vital financial source for many members, and equals to $57 \%$ of some state capital investments (EU average: $6.5 \%$ ). Besides an estimated number of SMES of 400,000 , also 121,400 new initiatives are financially supported, it is argued that the transport networks and transport ability have been extended, the fight against climate change is supported, the quality of life in cities increased etc.

However, in a report published in 2015 by the CPMR Secretariat ${ }^{2}$, the recent regional GDP statistics show that the regional differences increased, although the gaps between Member States expand, the gaps between regions within the same country increase as well (Figure 2).

\footnotetext{
willsupportprogrammesaddressingregionaldevelopment, economicchange, enhancedcompetitivenessandterritorialcooperationthroughoutthe EU. Fundingprioritiesincluderesearch, innovation, environmentalprotectionand risk prevention, whileinfrastructureinvestmentretains an important role, especially in theleastdevelopedregions.
}

The EuropeanSocialFund: The EuropeanSocialFund (ESF) will be implemented in linewiththeEuropeanEmploymentStrategyand it willfocus on fourkeyareas: increasingadaptability of workersandenterprises, enhancingaccesstoemploymentandparticipation in thelabour market, reinforcingsocialinclusionbycombatingdiscriminationandfacilitatingaccesstothelabour market fordisadvantagedpeople, andpromotingpartnershipfor reform in thefields of employmentandinclusion.

CohesionFund: ItappliestoMemberStateswith a GrossNationallncome (GNI) of lessthan $90 \%$ of theCommunityaveragewhichmeans it coversthenewMemberStates as well as GreeceandPortugal. Spainwill be eligibletotheCohesionFund on a transitionalbasis in thenewperiod, theFundwillcontributealongsidethe ERDF tomulti-annualinvestmentprogrammesmanaged. In a decentralisedway, ratherthanbeingsubjecttoindividualprojectapprovalbytheCommission. About 167.2 millionEuropeans (34.4\% of the EU-population) live in theregionscoveredbytheCohesionFund. Union, RegionalPolicy 2007, Cohesionpolicy2007-13).

EuropeanGrouping of TerritorialCooperation': TheEuropeanGrouping of TerritorialCooperation (EGTC) establishedbyArticle 159 of theTreatywhichfoundedtheEuropeanCommunityaimstoovercometheobstaclesin front of thecross-bordercooperation.

Thisgroupingshallimplementthecross-border program sor projects. National, regionalandlocalauthoritiesandotherorganizationsrecognized as publicinstitutionsorunions of suchinstitutionsfunction in accordancewiththecontractsconcluded(EuropeanUnion, RegionalPolicy 2007,

Cohesionpolicy2007-13).

InstrumentforPre-Accession Assistance: ThefinancialinstrumentsimplementedforTurkeyandBalkans in thepast(PHAE, ISPA, PreParticipationStructuralPolicy Media, Sapard CARDS (Support of theCommunityfor Re-structuring, Development andStability in theBalkans) andPre-Partipational Financial AidforTurkey), havebeenreplacedbylnstrumentforPre-accession Assistance(IPA) as of January2007.

1http://ec.europa.eu/regional_policy/sources/docgener/evaluation/pdf/expost2013/wp1_synthesis_factsheet_en.pdf

${ }^{2}$ CPMR Secretariat 2015, What do the recent regional GDP statistics tell us about Cohesion? CPMR Secretariat.Erişimtarihi: 10 Ekim 2016, http://cpmr.org/wp-content/uploads/2015/08/Analysis-from-the-CPMR-Secretariat-Regional-GDP-statistics-July-2015.pdf 
According to this report, if the average regional GDP of the years 2011, 2012 and 2013 is used, the compatibility of 32 regions will change within the scope of the cohesion policy. 31 of those 32 regions will fall one category (from "developed regions" to "transition regions") and only one region will raise by one category. One of those regions (Madeira, Portugal) will fall from the category of developed regions to the category of less developed regions.

Excluding the exception of Malta, all Member States of Mediterranean are worse and below the EU average:

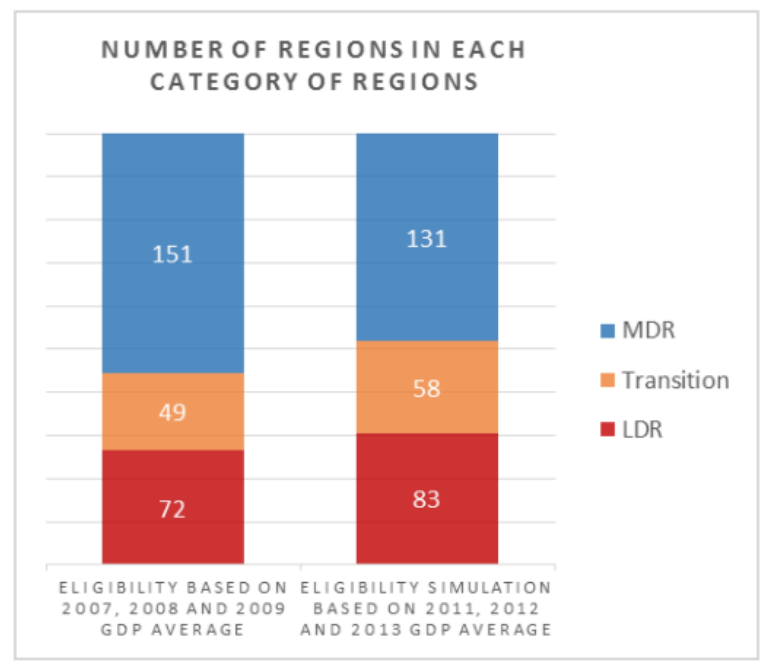

Figure 2: Number of regions in each category of regions

Source CPMR Secretariat by 2015

On the other hand,The lagging regions report" "Competitiveness in low-income and low-growth regions" identifies five main reasons as to why some regions have not yet reached the expected rate of growth and income:

The macroeconomic framework has a significant impact on regional economic growth.

Lagging regions have lower productivity, educational attainment and employment rates compared to the other regions in their country.

Underdeveloped regional innovation systems, skills gap and poor institutional quality undermine the growth potential of lagging regions.

The significant population losses in low-income regions and especially the out-migration of the younger and more educated population may limit their growth prospects.

Public and private investment dropped in these regions, especially in low-growth regions.

There are also some criticisms over the criteria used to assess whether or not regions are eligible for funds, and how these funds are then used? Objective 1 funding, which makes up two thirds of the structural funds, is only available in those EU regions (NUTS level 2) where GDP per capita is lower than $75 \%$ of the EU average. These criterias do not allow for inter regional disparities, and regions can find that they lose their eligibility for funding despite still having some very needy areas within them (Oktayer, N. 2007). However, as far as we know, there are no available studies presenting a counterfactual analysis, i.e., comparing their results with the situation without regional policies. This is particularly relevant since, if a 
particular region were not "better off" despite benefiting of EU's regional policies, this would not necessarily mean that the aid was not efficient, since the region might have been "even worse off" without that aid (Rivero\& others, 2005).

\section{The Europe 2020 Strategy and the $2014-2014$ Cohesion Policy}

The Europe 2020 Strategy, as a reaction of the European economy against globalization to the basic problems experienced at political level is a strategy prepared to overcome the structural problems of the economy of EU experienced across the globalization and in this sense, it is a resuming text that replaced the Lisbon Strategy (Akbaş, G. \&Apar, E., 2010).

The EU strategic report explains the economic and social reality of the EU as follows: :" The recent economic crisis has no precedent in our generation. The steady gains in economic growth and job creation witnessed over the last decade have been wiped out - our GDP fell by 4\% in 2009, our industrial production dropped back to the levels of the 1990s and 23 million people - or $10 \%$ of our active population - are now unemployed. The crisis has also made the task of securing future economic growth much more difficult. The still fragile situation of our financial system is holding back recovery as firms and households have difficulties to borrow, spend and invest. Our public finances have been severely affected, with deficits at $7 \%$ of GDP on average and debt levels at over $80 \%$ of GDP - two years of crisis erasing twenty years of fiscal consolidation. Our growth potential has been halved during the crisis. Many investment plans, talents and ideas risk going to waste because of uncertainties, sluggish demand and lack of funding."(EC,2010)

The scope of the Strategy can be read as an effort to find a solution by taking the structural economic - social problems surrounding the EU and ongoing economic and environmental problems on a global scale into consideration. The policies brought up by the strategical documents under the expression, "more unity outside and more coordination inside on the basis of this crisis and the approach to transform the current global crisis into an opportunity",it is emphasized that the member states should follow policies which are more holistic and sensitive to the priorities of EU and consistent practices" (Akbaş, G. \&Apar, e. 2010).

Europe 2020 puts forward three mutually reinforcing priorities ${ }^{1}$ to offer a vision of Europe's social market economy for the 21st century;

- Smart growth: developing an economy based on knowledge and innovation

- Sustainable growth: promoting a more resource efficient, greener and more competitive economy.

- Inclusive growth: fostering a high-employment economy delivering social and territorial cohesion.

and the Commission proposes the following EU headline targets:

- $75 \%$ of the population aged $20-64$ should be employed.

- $3 \%$ of the EU's GDP should be invested in R\&D.

- The "20/20/20" climate/energy targets should be met (including an increase to $30 \%$ of emissions reduction if the conditions are right).

- The share of early school leavers should be under $10 \%$ and at least $40 \%$ of the younger generation should have a tertiary degree.

- 20 million less people should be at risk of poverty. (EC, EUROPE 2020, 2010,pgh,.05-6).

The Strategy also foresees the following Flagship Initiatives:

"Innovation Union" to improve framework conditions and access to finance for research and innovation so as to ensure that innovative ideas can be turned into products and services that create growth and jobs.

"Youth on the move" to enhance the performance of education systems and to facilitate the entry of young people to the labour market.

\footnotetext{
${ }^{1}$ For details: (EC, EUROPE 2020, 3.3.2010, http://eur-lex.europa.eu/LexUriServ/)
} 
"A digital agenda for Europe" to speed up the roll-out of high-speed internet and reap the benefits of a digital single market for households and firms.

"Resource efficient Europe" to help decouple economic growth from the use of resources, support the shift towards a low carbon economy, increase the use of renewable energy sources, modernise our transport sector and promote energy efficiency.

"An industrial policy for the globalisation era" to improve the business environment, notably for SMEs, and to support the development of a strong and sustainable industrial base able to compete globally.

"An agenda for new skills and jobs" to moderniselabour markets and empower people by developing their of skills throughout the lifecycle with a view to increase labour participation and better match labour supply and demand, including through labour mobility.

"European platform against poverty" to ensure social and territorial cohesion such that the benefits of growth and jobs are widely shared and people experiencing poverty and social exclusion are enabled to live in dignity and take an active part in society.( (EC, EUROPE 2020, 2010,pgh,.05-6).

These seven flagship initiatives will commit both the EU and the Member States. EU-level instruments, notably the single market, financial levers and external policy tools, will be fully mobilised to tackle bottlenecks and deliver the Europe 2020 goals. As an immediate priority, the Commission charts what needs to be done to define a credible exit strategy, to pursue the reform of the financial system, to ensure budgetary consolidation for long-term growth, and to strengthen coordination within the Economic and Monetary Union.(ibid)

\subsection{The Europe 2020 Strategy and the Changes in the Cohesion Policies : The New Era ${ }^{1}$}

The scope of the last cohesion policy, Article 174, Treaty of Lisbon (2010) has been described as: 'In order to promote its overall harmonious development, the Union shall develop and pursue its actions leading to the strengthening of its economic, social and territorial cohesion. In particular, the Union shall aim at reducing disparities between the levels of development of the various regions and the backwardness of the least favored regions".

The new cohesion policy aiming not only the less developed regions,but all 274 regions of the Union,became the main investment policy and is associated directly with the objectives of the Europe 2020 Strategy. In this context, principles such as thematic concentration, result orientation and the use of appropriate financial instruments are very important.

What's new in 2014-2020 Cohesion Policy?

The EU budget period fits to the current Strategy's objectives ;

Focus on results

Performance reserve: 6\% funding allocated in 2019 to programmes and priorities which have achieved $85 \%$ of their milestones.

Necessity of pre-conditions for an effective EU investment: Thematic ex ante conditionalities (Linked to the thematic objectives and

investment priorities of Cohesion Policy and applied in relation to investments in the specific thematic area: strategic, regulatory and institutional pre-conditions, administrative capacity), General ex ante conditionalities (Linked to horizontal aspects of programme implementation and apply across all ESI funds: anti-discrimination policy, gender equality policy).

1 The "A Cohesion Policy Agenda on the basis of reforms", published in 2009, aims to form an integrated vision for Europe 2020 Strategy. The report suggestedto combine the spatial integration with the socio-economic integration, in addition, the spatial integration to play a central role in the integration of the EU. With this approach, both the development of local policies as well as strengtheningthe regional and local actorsit areaimed. The simplification of management and control mechanisms is among the innovations proposed by this report. For details: Samecki, P., 2009. Orieantation Paper on Future Cohesion Policy. European Comission in charge of Regional Policy, Brussels. 
Cohesion policy is part of the European Structural \& Investment Funds (ERDF, EAFRDCohesion Fund, ESF,EFF) for the period 2014-2020, 454 billion Euros have been allocated to represent the second largest portion of the EU budget.

In order to ensure the investments to be focused, most of the ERDF, will be spent on the fields under four big growth objectives (Research and Innovation, SMEs, ICT and the low-carbon economy). At least $80 \%$ of the resources available in the more developed regions and $50 \%$ of the resources available in less developed countries shall be allocated to major sectors within the growth objectives. There are similar rules for the ESF and at least $20 \%$ of the total ESF resources shall be used for encouraging social inclusion and the fight against poverty.

Different allocation ratios have been assigned in accordance with the level of development of regions (underdeveloped regions: 50\%, transition regions: $60 \%$ and developed regions:: 80\%) (EC, 2014). At least 26 billion Euros of these funds shall support low-carbon economy (energy efficiency and renewable energy). Besides, in the distribution of ERDF resources, there are 3 separate obligations ${ }^{1}$.

Thanks to the European Social Fund (ESF), the cohesion policy, will provide a significant contribution to the EU priorities in the field of employment through for example education, lifelong learning, social inclusion etc. At least $20 \%$ of the total ESF resources shall be allocated for encouraging social inclusion and the fight against poverty. At the same time, the new youth employment Initiative linked with the ESF will provide a special focus on young people (EC, 2014).

When the national contribution of the Member States and leverage effect of the financial instruments are combined, the overall economic impact of the cohesion policy in the new period, is expected to be more than 500 billion Euros.

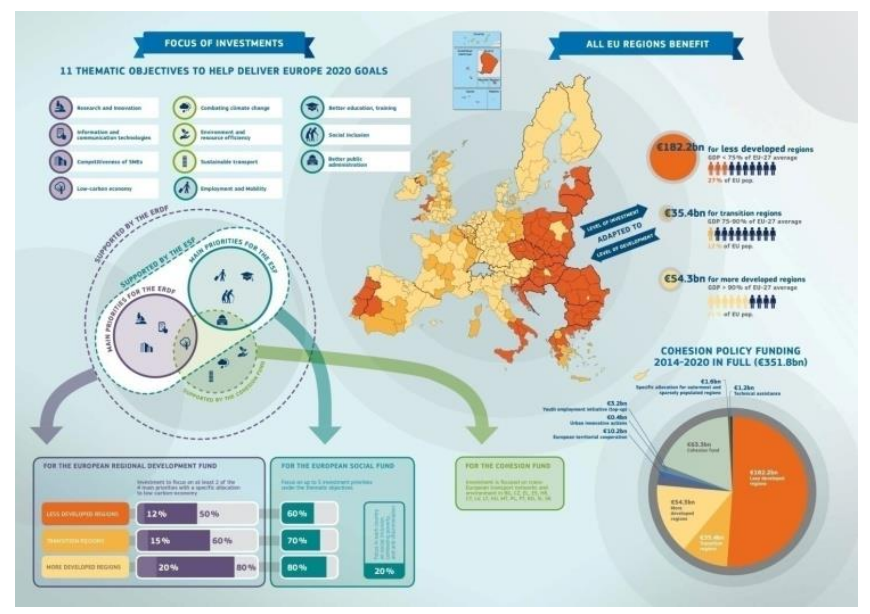

Figure 3 How does the 2014-2020 Cohesion Policy shape Europe 2020 Strategy's objectives

Source: PANORAMA: Cohesion Policy 2014 - 2020 Nr: 48 Winter 2014

Between 2014 and 2016, the Funds are expected to account for approximately 14\% of total public investment on average, and even to reach up to $70 \%$ in some Member States.

\footnotetext{
1 For details: (PANORAMA: Cohesion Policy 2014 - 2020:48 Winter 2014).
} 


\section{Proportion of ESI Funds in public investment}

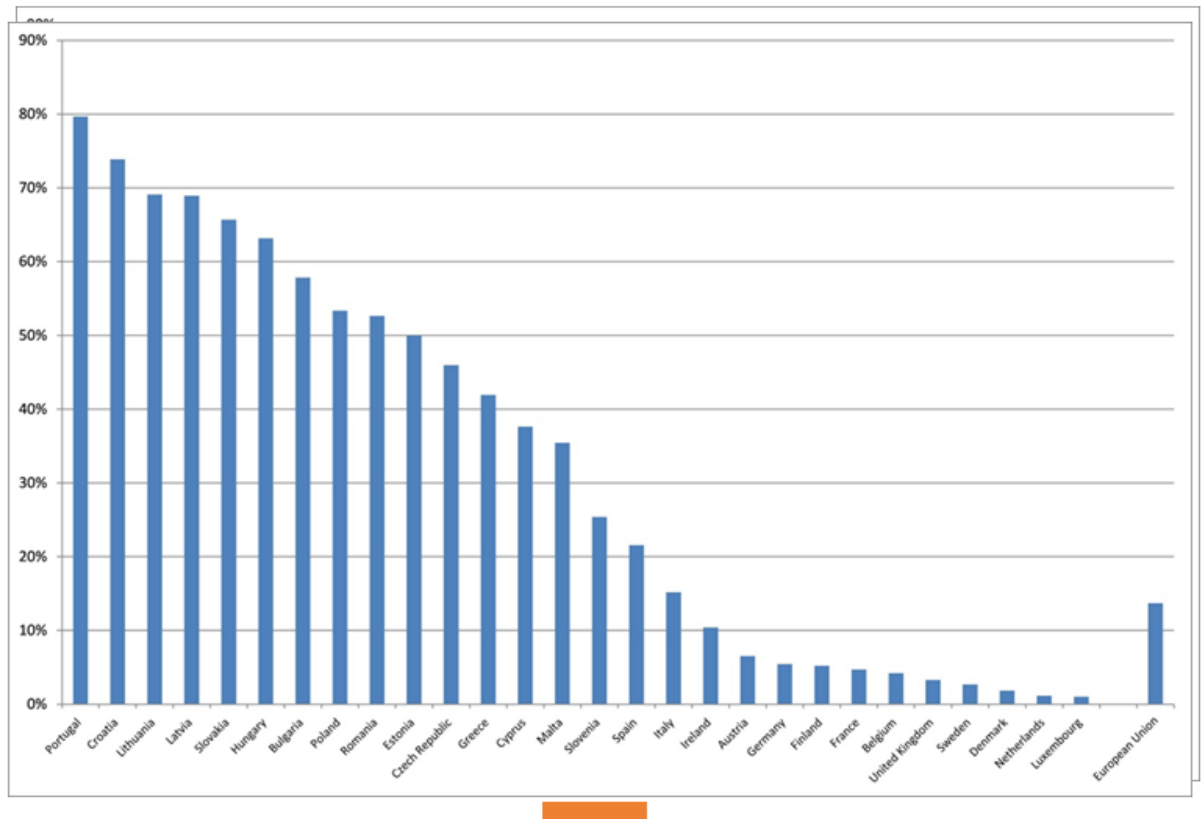

Figure 4: Proportion of ESI Funds of public investment

2.2.Urban Dimension and "An EU Urban Agenda for the Smart Cities of the Future" of the Cohesion Policies for the Period 2014-2020,

The cities, where more than two-thirds of the total GDP of EU is produced, are regarded as the very important actors in achieving Europe's 2020 targets. In overcoming the economic crisis, in addition to the development of existing facilities of the cities,investment capacities to attract investments are also sought. Moreover, the cities and urban areas have a key role not only in terms of urban congestion and propagation, protection of environment and resources, climate changes and reduction of GHG emissions as well as in economic, social\& and territorial cohesion policies. Within the framework of this prediction,the Former Regional Policy General Directorate has been reorganized as the Regional and Urban Policy General Directorate for the new period by the EU Commission.

In the terms of financing; most of the investment priorities in the period of 2014-2020 were relevant initiatives in the fields of development of low-carbon strategies, improvement of the built environment or facilitating mobility within the urban areas and this ratio is expected to increase. For more, each Member State is obligated to spend at least $5 \%$ of ERDF for integrated actions for sustainable urban development.

The Urban Europe 2020 Strategy was developed by the 'European Innovative Partnership for 'Smart Cities and Communities" ((EIP-SCC), a Stakeholder Platform Member, to enrich the EU Strategy 2020 and to develop Smart Cities of the Future.

The priorities and initiatives of the Urban Europe, designed as an integrated strategy for the Smart, Sustainable and Comprehensive Urban Development of European cities and communities in order to enrich Europe 2020 have been described as follows;

I. Smart Communities and Cities: Knowledge and innovation based (Innovation; Education; Digital Society) development of social and urban economy; 
II. Sustainable Communities and Cities: Promoting more resource efficient, greener and more competitive communities and cities (Climate, Energyand Mobility; Competition);

III. Comprehensive Communities and Cities: Promoting a social and urban economy based on high employment to provide social and regional integration (Employment and Skills; Fight Against Poverty) (Urban Europe 2020: An EU Urban Agenda for the Smart Cities of Tomorrow).

\section{Conclusion}

It is seen that the regional / cohesive policies of EU and the distribution of the funds and budgets from the beginning until today have been associated with the spatial expansion and with the levels of the community's economic and social development. Since the early periods of the ERDF (1973), the regions under the $75 \%$ of the average (Target 1 ) and the problematic urban areas in economic and social sense have been supported. It is seen that ESF, which was established by the founding Treaty of Rome (1958), provided partial support to the target 1 regions. But the EU funds operated separately until the SEA (1986). On the other hand, the EU funding has a completing role in the period of 1970s-1986. All funds of the EU were integrated under the Structural funds after the SEA (1986), as the first structural change in the regional and fund structures. In that period, the effectivity of the Union scale for the regional policies and usage of the funds seemed to have increased.

The 2000 Lisbon \& Europe 2020 strategies and the EU regional/cohesion policies and structural funds are considered as a new period when the strategic approach was strengthened in association with the expenditures.

At the scale of Europe after the period 2000-2006, the EU funds have been integrated within the scope of 3 objectives within the framework of "convergence, competitionand regional cooperation"strategies. However, the impacts of the global economic crisis in front of the achievement of the Lisbon Strategy objectives within the process and the critics about the economic social structure within the Union focused on "Smart growth, Sustainablegrowth, and Inclusive growth" with the 2020 Europe Strategy on the axis of the coherence/regionalpolicy.

\begin{tabular}{|c|c|c|c|c|c|c|c|c|}
\hline \multirow{2}{*}{\begin{tabular}{|l|} 
PERIOD \\
TOTAL BUDGET \\
\end{tabular}} & \multicolumn{2}{|c|}{$2000-2006$} & \multicolumn{3}{|c|}{$2007-2013$} & \multicolumn{3}{|c|}{$2014-2020$} \\
\hline & \multicolumn{2}{|c|}{$€ 195 \mathrm{bn}$} & \multicolumn{3}{|c|}{$€ 374 \mathrm{bn}$} & \multicolumn{3}{|c|}{$€ 351.8 \mathrm{bn}$} \\
\hline DISTRIBUTION & Budget $(€$ bn) & $\%$ of T.B* & Distribution & Budget & $\%$ of T.B & Distribution & Budget & $\%$ of T.B \\
\hline Obefive 1 & 136.5 & 70 & Convergence & 305.5 & 81.7 & Less Developed Regions & 182.2 & 51.7 \\
\hline Obefive 2 & 22.4 & 11.5 & Regional Competitiveness & 59 & 15.8 & Cohesion Fund & 63.3 & 18 \\
\hline Obefive 3 & 23.4 & 12 & Territoral Cooperation & 9.1 & 2.44 & More Dev. Regions & 54.3 & 15 \\
\hline & & & & & & Transition Regions & 35.4 & 10 \\
\hline & & & & & & E.Terriorial Cooperation & 10.2 & 2.8 \\
\hline & & & & & & Youth employment Initiative & 3.2 & 0.9 \\
\hline & & & & & & Specific Allocation** & 1.6 & 0.45 \\
\hline & & & & & & \begin{tabular}{|l|} 
Technical Assistance \\
\end{tabular} & 1.2 & 0.34 \\
\hline & & & & & & Urban Innovative Actions & 0.4 & 0.1 \\
\hline
\end{tabular}

* Total Budget

** Specific Allocation for Outermost and sparsely populated regions

Table : Budget of Cohesion Policy during 3 different periods

Source: Authors of this Article

The Europe 2020 Strategy appears as a rather complex structure when the policy options, developed within the framework of all headings and their links with each other despite of the simplified priorities for the realization of the vision and the basic initiative headings are identified within the context of such priorities. In this sense, the critic to the Lisbon Strategy to be too complex, is valid also for the Lisbon Strategy. In addition, since all of the objectives aimed to be achieved will be formed on an economic-social ground, the reality that such ground is interacting with the changes at the global level, can be regarded as the othe problem against the achievement of the objectives. 
Though the final objectives are clearly specified, the national criterion of EU to be described as $28-1$ and the economicsocial indicators expressed in hundreds consisting of different regional scales is one of the key problematics in achieving the strategy.

The one by one association of the strategic proposition with the EU policies and creation of agendas at the level of each sector at the scale of commission can be shown as the strengths.

Moreover, for the Member States to develop programs complying with the 2020 objectives, creating a reporting system andEU Council to be responsible for the management of the strategy are regarded as the positive aspects of the Lisbon Strategy (Akbaş, G. \&Apar, E., 2010).

Despite of the complex structure of the priority and initiative headings of the strategy, the determinations in association with the existing conditions in the introduction text of the strategy document and the claimed objectives show that the strategy focuses on the solution of the problem of unemployment, which increased after the crisis in the EU, completion of economic common market and increasing the competition power of the EU economy with North America and China.

The subheadings of smart and sustainable development priorities, particularly under an industrial policy for the globalisation era; heading towards EU innovative technologies and clean energy sources, the manufacturing industry, having an important place in the EU economy and raising the competitiveness of SMEs and creating new employment opportunities seem to be very important. Under the priority sustainable growth; development of alternative integrated systems in combating against climate changes and the reduction of $\mathrm{C0} 2$ level in the transportation networks and infrastructure, reduction of the share of natural resources in energy consumption and raising the protection of natural sources and sustainable development are intended.

A clear framework was aimed at the scale of EU and for the member states by detailing the the problems of employment, approaches on the social security system, increasing social and territorial cohesion which were the essence of Lisbon Strategy are maintained in the Europe 202 Strategy and under the heading of Priority of Comprehensive Growth, social problems, especially such as increasing poverty, access to adequate education, social gender and ageing population.

In current cohesion policies and funding, about $2 / 3$ of the total budget is alocated to less developed and transit regions, thus it is anticipated that it will be effective in achieving the objectives of the strategy.

\section{References}

[1] Selin, A. 2014. Avrupa 2020 Stratejisi. İktisadi Kalınma Vakfı Yayınları, İstanbul

[2] Akbaş, G. \& Apar, E. 2010. Avrupa 2020 Stratejisi: Akıllı, Sürdürülebilir Ve Kapsayıcı Büyüme İçin Avrupa Stratejisi - Özet Bilgi Notu. T.C. Başbakanlık - Avrupa Birliği Genel Sekreterliği - Sosyal, Bölgesel ve Yenilikçi Politikalar Başkanlığı, Ankara.

[3] Allen,D,2005," Policy -Cohesion And The Structural Funds" Policy-Making In The EU, Wallece ,H.,Walles,W, And Pollak,A.Mark, Okford Universty.Press)

[4] CPMR Secretariat 2015, What do the recent regional GDP statistics tell us about Cohesion? CPMR Secretariat. http://cpmr.org/wp-content/uploads/2015/08/Analysis-from-the-CPMR-Secretariat-Regional-GDP-statisticsJuly-2015.pdf

[5] European Comission - The New EU Cohesion Policy (2007-2013), https://www.euractiv.com/section/regionalpolicy/linksdossier/the-new-eu-cohesion-policy-2007-2013-archived/

[6] European Commission, Integrated Sustainable Urban Development, http://www.eukn.eu/fileadmin/Lib/files/EUKN/2013/integrated\%20urban\%20sustainable\%20development $\% 20 \mathrm{E}$ C\%20factsheet.pdf

[7] European Commission Brussels, 10.4.2017 SWD(2017) 132 Final Commission Staff Working Document: Competitiveness in low-income and low-growth regions The lagging regions report.

[8] European Union, Regional Policy 2007, Cohesion policy 2007-13: Commentaries and official texts. European Union, Regional Policy, Brussels.

[9] German Institute for Economic Research and European Policies Research Centre, The Impact of European Union Enlargement on Cohesion-Backround Study for the 2nd Cohesion 2001).

[10] İnan Alpan, 2005. Avrupa Birliği Ekonomik Yaklaşımı:Lizbon Stratejisi ve Maastricht Kriterleri. Bankacılar Dergisi, Sayı 52. 
[11] İncekara, A. \& Kııınç Savrul, B. Avrupa Birliği Bölgesel Kalkınma Politikaları: Yapısal Fonlar ve Diğer Mali Araçlar Çerçevesinde Bir Değerlendirme. Erişim tarihi 05 Kasım 2016, http://abs.cu.edu.tr/Dokumanlar/2016/PF\%20434/545318283_avrupa_birligi_bolgesel_kalkinma_politikalari.pd $f$

[12] OKTAYER ,Nagihan, 2007. Regional Policy And Structural Funds In The European Union: The problem of effectiveness. Ankara Review of European Studies Vol: 7, No:1 (Fall: 2007), p.113-130.

[13] Paul M. Romer. "Endogenous Technological Change", Journal of Political Economy, V. 98. 5, 1990, p. 71-102. Robert E. Jr. Lucas, "On the Mechanics of Economic Development", Journal of Monetary Economics, V. 22. 1, 1988, p.3-42.

[14] PANORAMA: Cohesion Policy 2014 - 2020:48 Winter 2014.

[15] Pere G. Porquerasve Enrique Garcilazo, EU Structural and Cohesion Funds in Spain and Portugal: Is Regional and National Inequality Increasing?, Mianii European Union Center, Working Paper Series, Vol. 3, No: 11, 2003.

[16] Robert M. Solow, "A Contribution to the Theory of Economic Growth", The Quarterly Journal of Economics, V. 70. I, 1956, p.65-94.).

[17] Romer. Paul M. "Endogenous Technological Change", Journal of Political Economy, V. 98. 5, 1990, p. 71-102. Robert E. Jr. Lucas, "On the Mechanics of Economic Development", Journal of Monetary Economics, V. 22.1, 1988 , p.3-42.

[18] Samecki, P., 2009. Orieantation Paper on Future Cohesion Policy. European Comission in charge of Regional Policy, Brussels.

[19] SimónSosvilla-Rivero, Oscar Bajo-Rubio \& Carmen Díaz-Roldán, 2005. Assessing The Effectiveness Of Eu'sRegional Policies On RealConvergence: An Analysis Based OnThe Hermin Model.

[20] Urban Europe 2020: An EU Urban Agenda for the Smart Cities of Tomorrow, Erişim tarihi 15 Kasım 2016, https://eu-smartcities.eu/blog/urban-europe-2020-eu-urban-agenda-smart-cities-tomorrow

[21] 9 Ways Cohesion Policy Works For Europe - Main Results 2007-2013. Erişim tarihi 10 Ekim 2016,

[22] http://ec.europa.eu/regional_policy/sources/docgener/evaluation/pdf/expost2013/wp1_synthesis_factsheet_en. pdf

[23] http://ec.europa.eu/regional_policy/sources/docgener/studies/pdf/citiesoftomorrow/citiesoftomorrow_final.pd 